\title{
Em busca de Companhia: o universo da prosa final de Samuel Beckett
}

\author{
Bueloni Gonçalves, Lívia (2018).
}

São Paulo: Humanitas / FAPESP.

\section{0}

Thiago Souza Pimentel

Pontificia Universidade Católica, Minas Gerais, Brasil

Ocupándose de la prosa final de Samuel Beckett, y haciendo foco en especial en la obra Company, Lívia Bueloni Gonçalves (UFMG) pone de relieve una sinuosa relación de dependencia entre el narrador, que anhela el silencio, y la narrativa, a la que no se la deja de atacar. Su hipótesis consiste en la posibilidad de aprehender lo que ella llama un "mecanismo de búsqueda de compañía", y concuerda con la postura de una lectora "iniciada". Es decir, de alguien que, si bien reconoce las dificultades inherentes a un discurso cuya palabra ha colapsado, valida la capacidad que la obra -repleta de dudas y conflictos- tiene todavía de proporcionar compañía. Con el mismo espíritu del narrador beckettiano, la lectora insiste. Busca traerle al universo de Beckett "un poco de luz".

El primer capítulo de Em busca de Companhia: o universo da prosa final de Samuel Beckett presenta las tres etapas que traza el persistente narrador beckettiano -éste que no obstante la frustración con las palabras, y aunque disconforme con lo que busca representar, todavía continúa-. Ilustrándola con puntos de vista de otros críticos, Bueloni justifica su metodología no sin enfatizar que, conforme a la complejidad misma de los textos de Beckett, toda clasificación es apenas una posibilidad limitada.

Ya en la temprana actividad docente ejercida por Beckett a finales de los años 20, observa que sus decisiones respecto de qué enseñar hablan más que de preferencias literarias: son, asimismo, representativas de un sentimiento general hacia la literatura como arte que refleja la "incapacidad de proveer un retrato seguro de la realidad" (p. 42). Así, subrayando la relación con el francés (antes incluso de su uso literario), es que Bueloni parte del primer giro decisivo que Beckett le da a su ficción -en el límite de la "angustia de la influencia" de James Joyce entre otros-, para analizar de modo más cercano la segunda fase de su literatura. Sin dejar de considerar fundamental el contexto posterior a la Segunda Guerra Mundial, argumenta que en esa etapa el cambio lingüístico expresado por personajes vacilantes, que narran sus deambulaciones entre los escombros de una ciudad arrasada, y que implica todo un "empobrecimiento" del lenguaje, suscita, entretanto, una sugestiva reflexión acerca de la "relación entre la acumulación de conocimiento y la búsqueda declarada de la ignorancia” (p. 44).

Es en esta fase que aparece la figura del narrador en primera persona. Parafraseando a la autora: este narrador-protagonista perturbado y emblemático (al menos de esta fase), desplazado de su lugar de origen, puesto en movimiento en contra de su propia voluntad, es quien se encargará de contar la historia de su peregrinación por esa ciudad indefinida. Así es como este narrador se ocupa de las incertezas que le quedan: de los cuestionamientos acerca del "cómo decir" que atraviesan toda esa segunda etapa, que se extiende desde las novelas en francés hasta los Textes pour rien (1955), pasando por la trilogía compuesta por Molloy, Malone meurt (1951, ambas) y L'innommable (1953): “Obras en las que la forma de expresión es tan cuestionada como el propio valor y la necesidad de la narración" (p. 48).

La autora da continuidad al análisis de esa búsqueda de una forma que es tanto crítica de los moldes tradicionales del género novelesco, como intento inasequible de encontrar un escape para el impasse de la escritura, resaltando cómo progresivamente Beckett ha transformado en tema el propio conflicto: entre la insatisfacción con el modo de expresarse en palabras y la necesidad misma de narrar -un conflicto, claro está, que no se resuelve-. En el borde de esa segunda fase, se encuentra L'innommable, obra que, según afirma Bueloni, si bien inaugura un "retroceso hacia la interioridad" (p. 54), típico de los textos de la tercera y última fase de Beckett, debe ser encarada, antes, como la culminación de un proceso de exploración (de la primera persona narrativa), que como el comienzo de la etapa final de su ficción. 
En el capítulo siguiente, Bueloni se adentra en la tercera fase de la literatura de Beckett. Su objetivo es presentar el universo de la prosa beckettiana en el que "finitud y 'exploración de la mente' se retroalimentan" (p. 74). La figura del cráneo se vuelve para la autora el centro de la creatividad, simbolizando así el trabajo mental.

Empezando por Company (1980), Bueloni afirma que en esta obra la imaginación es "soberana". Es decir, si bien la obra conjuga las tres instancias, biografía, ficción y recepción, con el objetivo de volver a contar una historia de vida, su intención es manifestar las fallas de este intento. De modo que, preguntándose sobre "qué podría tomarse como 'real'," lo que Beckett hace es, ante todo, problematizar "la capacidad del lenguaje y de la escritura de conferir algún sentido o de reconstruir una historia de vida" (p. 79). En la secuencia del análisis, son resaltadas por la autora algunas interesantes diferencias en lo que concierne a aspectos comunes de las obras de Beckett. Así, si anteriormente se la toma como algo que coacciona al protagonista, obligado en contra de su voluntad a dar secuencia a su discurso, ahora la voz tiene autonomía. Ha dejado de ser una voz interna del narrador para, manifestándose directamente en el texto, continuar impidiendo que éste alcance el silencio. Ese movimiento coincide con el retroceso del protagonista errante, perturbado por la voz, hacia el protagonista inmóvil, receptor de aquella. En lugar del sujeto de la experiencia, el foco es el propio proceso de creación. Todo eso corrobora el lugar destacado conferido a la imaginación en esta obra.

Progresivamente, se nota en la lectura que Bueloni hace de las obras que el problema del impasse se afirma como una constante en Beckett y, a medida que aquéllas evolucionan, este adquiere nuevos contornos. En III Seen III Said (1981), cuya belleza, afirma la autora, “más allá de la exploración lingüística [...] deriva justamente de la configuración dada [al] narrar" (p. 91), lo mal dicho se hace significativo. Otra vez, se narra desde el interior de la mente. La novedad, sin embargo, es la presencia del hoyo como segunda instancia narrativa. Si en esa obra la imagen tiene un sentido apelativo -observable en las oposiciones blanco/ negro, claro/oscuro-, el hoyo es el responsable de su captación mientras el narrador trata de expresarla en palabras. Innecesario es decir que ese intento conjunto es marcado por la falla. Dispersas, las imágenes se vuelven inaprehensibles, y a eso se asocia la dificultad de decir: a la palabra, afirma Bueloni, se la considera traidora. Por otro lado, como las imágenes no cesan de surgir, el narrador nuevamente es compelido a continuar su actividad de (mal) decir lo que ve (mal). De ahí el motivo de Beckett de crear "un nuevo lenguaje para representar esa otra forma de 'ver', apartada de las leyes ya establecidas por el uso común” (p. 98).

Bueloni cierra su lectura de la tercera fase abordando Worstward Ho (1983), obra en la que recurrentes cuestiones se reimprimen con un carácter todavía más radical. "Movimiento intenso por el maldecir" (p.110), comenta la autora, dicha obra es, sin duda, un trabajo de experimentación singular. Sonoro, repetitivo, musical: quiere alcanzar el valor mínimo de la palabra colapsada -de ahí, la idea de Bueloni de "una exploración que se da en llave negativa" (p. 110)-. En esta obra extrema, el lector es invitado a perderse. Ahora bien, si la palabra es callada, las recurrentes preguntas que permean la obra conducen, otra vez, al impasse. El movimiento, según Bueloni, es opuesto al expansivo, encontrado en la prosa inicial de Beckett. Su dirección es hacia el confinamiento, donde se llega cavando agujeros en el lenguaje -toda una incansable persecución de una "literatura de la despalabra" (p. 117)-.

Esta segunda parte de su libro, en la que trata de los modos y posibilidades de representación (incluso de su abolición) en la fase final de la prosa beckettiana, se cierra con el repaso cuidadoso de algunos puntos importantes relativos a ese período. Por ejemplo, la mudanza del "hombre errante solitario" al "hombre aprisionado [que vive de] la observación de un otro" (pp. 118-119). La admisión de otros recursos que, no obstante, "continúan dependientes de la gastada palabra para concretarse”. O, aún, la propia idea de "romper con su materialidad, crear nuevas formas posibles para su empleo" (p. 119). En todo caso, si la prosa de Beckett "acabó por construirse dando forma [a un] impasse” (p. 118) -este que Bueloni menciona y comenta con dedicada insistencia-, esto implica una contraparte: la reivindicación de Beckett de una postura activa e innovadora de parte de sus lectores.

Finalmente, en el último capítulo de su libro, Bueloni argumenta que el tema de la compañía siempre estuvo presente en Beckett. Sea en la trilogía de posguerra, cuestionadora de la forma de la novela, en la que el propio acto de narrar configura la compañía buscada; sea en su prosa final, cuyo particular modo de autorreflexión, al involucrar en la narrativa al escritor, lector y protagonista, ha permitido entender la obra como compañía en sí misma.

En Company, la voz es uno de los elementos sobresalientes en los que Bueloni se enfoca, a fin de reflexionar sobre el tema de la compañía. Autónoma y visible, ya que asume características físicas, la voz, ahora exterior al personaje, se ha hecho ella misma un narrador 
al lado del narrador. Además, todavía más original es la consideración que la autora hace respecto de la asociación de esa voz a una segunda persona narrativa. Según su interpretación, eso respondería tanto a una crítica de la narración tradicional (con un narrador omnisciente), como a un alejamiento de la primera persona, agotada en las obras de la segunda fase. Es decir, la voz es también un camino para seguir adelante. Dejando de tener un rol negativo -responsable del silencio inalcanzable anhelado por el narrador-para asumir una función que rivaliza con la del narrador, la voz fragmenta el discurso al encargarse de una narración lineal que, como se sabe, sería imposible para el típico narrador beckettiano. En efecto, es asaz intencionada la confusión narrativa que se observa en Company.

Lo ficcional es otro elemento analizado. Para la autora, en esta última fase se establece una relación entre la intensificación de las fallas del lenguaje y el movimiento hacia el interior de sí de los personajes. "El acto de narrar [...] adquiere gran importancia en ese mundo solipsista ya que pasa a ser, justamente, la única compañía posible" (p. 145). Hasta incluso la confusión que se configura, bajo el empleo del pronombre "tú", que simultáneamente atañe al personaje-oyente y el lector de la obra, implica la interpretación de ésta como compañía: "La obra se cierra con esa ambigüedad. Hay una referencia a la soledad del sujeto aliada a todo lo que su propia imaginación puede crear para proporcionarle compañía" (p. 155).

El estudio termina afirmando que las búsquedas del narrador beckettiano no concluyen. Si por un lado Company recupera cierta accesibilidad a una historia que es contada, por otro consolida el impasse respecto a cómo hacerlo. Lo que le queda al narrador beckettiano es también aquello que lo sostiene: el propio proceso de intentar. Al final, pregunto: ¿y para nosotros, no sería igualmente un "intentar leer mejor" lo que nos fascina y nos mantiene lectores de Beckett? 